\title{
IMPLEMENTASI PEMBELAJARAN AKTIF (ACTIVE LEARNING) UNTUK MENINGKATKAN KOMPETENSI SPIRITUAL DAN SOSIAL SISWA DALAM PEMBELAJARAN PENDIDIKAN PANCASILA
}

\author{
Yayat Sudrajat \\ SMK Negeri Pancatengah, Kabupaten Tasikmalaya, Jawa Barat \\ Email: yatsukma@gmail.com
}

\begin{abstract}
ABSTRAK
Penelitian ini dilatarbelakangi oleh keadaan guru saat ini yang dituntut untuk mampu merancang pembelajaran efektif dan bermakna, menyenangkan, bisa mengorganisasi pembelajaran dengan baik, memilih pendekatan atau model pembelajaran yang tepat sehingga siswa dapat aktif belajar dan menjadikan pembelajaran berpusat pada siswa dengan harapan oleh karenanya akan terjadi peningkatan kompetensi sikap sosial, sikap spiritual, pengetahuan dan keterampilannya. Hal tersebut tercermin melalui hasil pembelajarannya. Penelitian ini bermaksud untuk melihat bagaimana implementasi pembelajaran aktif melalui penerapan model-modelnya dalam pembelajaran PPKn di SMK Negeri Pancatengah dapat meningkatkan kompetensi spiritual dan sosial siswa. Penelitian ini dilandasi grand teori belajar konstruktivisme, pembelajaran aktif dari Bonwell (1995), Active Learning dari L. Dee Fink (1999), teori sikap dari Allport (1981) konsep sikap sosial dan spiritual dari Mulyasa (2015:17). Pendekatan yang digunakan dalam penelitian ini adalah kualitatif dengan metode deskriptif. Pengumpulan data dilakukan melalui observasi, wawancara, studi dokumentasi, dan studi literatur. Analisis data menggunakan langkah pengumpulan data, penyajian data, reduksi data, dan verifikasi/ kesimpulan data. Hasil penelitian menunjukan bahwa guru telah cukup memahami konsep dan implementasi pembelajaran aktif dengan mempraktekannya dalam penerapan beberapa model pembelajaran aktif diantaranya model pembelajaran Problem Based Learning, Inquiry Learning, Discovery Learning, dan Project Based Learning. Perencanaan pembelajaran aktif telah dilakukan secara menyeluruh. Dalam pelaksanaan pembelajaran aktif guru PPKn telah menunjukkan langkah penerapan model pembelajaran aktif dengan sistematis. Dalam pelaksanaan penilaian pembelajarannya telah menunjukan hasil yang objektif sejalan dengan peningkatan kompetensi sikap spiritual dan sosial siswa. Dukungan dan tantangan dalam implementasinya tidak terlalu berpengaruh dalam pelaksanaanya sehingga implementasi pembelajaran aktif menunjukan keberhasilan meningkatkan kompetensi sikap siswa. Rekomendasi dari penelitian ini meliputi: Pertama, pihak sekolah terus memberikan dukungan sepenuhnya dalam peningkatan pemahaman guru terhadap konsep dan prinsip pembelajaran aktif, Kedua, guru diharapkan untuk melek model dan strategi pembelajaran dengan menumbuhkan keinginan untuk terus menjadi guru pembelajar. Ketiga, sekolah terus membudayakan penerapan model-model pembelajaran dan memberi keleluasaan kepada guru dan siswa untuk melakukan inovasi pembelajaran. Keempat: mendorong guru untuk melakukan penelitian kelas atau penelitian lainnya.
\end{abstract}

Kata kunci: Pembelajaran aktif, sikap sosial dan spiritual, pembelajaran PPKn 


\begin{abstract}
This research is inspired by teachers' current state which is demanded to have competencies in designing effective and meaningful learning, fun, organizing the learning well, choosing the right approach or learning model so students can actively learn and create a studentcentered learning. It is expected to enhance the competence of social attitudes, spiritual attitudes, knowledge, and skills. The enhancement itself can be seen through the results of the learning assessment. This study intends to see the implementation of active learning through the application of Pancasila and Civics education models at SMK Negeri Pancatengah which can improve students' spiritual and social competences. This research is based on Piaget and Vygotsky's constructivist learning theory, Active Learning from Silberman (2014:9), Active Learning from Warsono (2013:5), Attitude theory from Mar'at (1982:13), the concept of social and spiritual attitudes from Mulyasa (2015:17). The approach used in this research is qualitative with descriptive method. The process of collecting data is conducted through observation, interview, documentation study, and literature study. Meanwhile, the stages of data analysis are in the form of data collection, data presentation, data reduction, and data verification/conclusion. The results of the study found by the researcher stated that the teacher has understood the concept and implementation of active learning by practicing it in the application of some active learning models such as problem-based learning, Inquiry Learning, Discovery Learning, and Project-Based Learning. Active learning plan has been carried out thoroughly. In the implementation of active learning, the teacher has demonstrated the step of applying the active learning model systematically. The implementation of the learning assessment has shown objective results in line with the improvement of students' competencies of spiritual and social attitudes. In its implementation, the supports and challenges are not very influential so the implementation of active learning shows the success of improvement towards the competence of students' attitude. Recommendations from this study include: First, The school continually provides moral and material support, especially in terms of improving teachers' understanding of the concepts and principles of active learning, Second, The teacher is expected to be aware of models and learning strategies by growing the desire to be a learner teacher. Third, The school continues to cultivate the application of learning models and provide flexibility to teachers and students for learning innovation. Fourth: Encourage teachers to conduct classroom research or other research.
\end{abstract}

Keywords: Active Learning, social \& spiritual attitudes, Pancasila and civic education learning

\title{
PENDAHULUAN
}

Semenjak diberlakukannya sistem kurikulum 2013 jilid satu yaitu tepatnya pada tanggal 15 Agustus Tahun 2013 oleh menteri Pendidikan dan Kebudayaan saat itu yaitu Mohammad Nuh dan selanjutnya dihentikan sementara implementasinya oleh menteri penggantinya Anis Baswedan Tahun 2014 dan selanjutnya diberlakukan kembali Kurikulum 2013 jilid dua pada bulan Juli 2016, tujuan utamanya tetap sama yaitu terciptanya pembelajaran efektif dan bermakna.

Tujuan pembelajaran efektif dan bermakna dalam Kurikulum 2013 adalah menghasilkan insan Indonesia yang produktif, kreatif, inovatif, afektif, melalui penguatan 


\section{AoEJ : Academy of Education Journal \\ Vol. 11 No 2 Tahun 2020}

sikap, keterampilan, dan pengetahuan yang terintegrasi. Untuk mewujudkan hal tersebut, dalam implementasinya guru dituntut untuk merancang pembelajaran efektif dan bermakna, menyenangkan, mengorganisasi pembelajaran dengan baik, memilih pendekatan pembelajaran yang tepat, menentukan prosedur pembelajaran dan pembentukan kompetensi secara efektif serta menetapkan kriteria keberhasilannya (Mulyasa, 2013, hlm. 99). Sesuai dengan kalimat pendahuluan dalam Permendikbud Nomor 22 tahun 2016 tentang standar proses pendidikan disebutkan bahwa proses pembelajaran dalam Kurikulum 2013 diselenggarakan secara interaktif, menyenangkan, menantang, inspiratif, memotivasi peserta didik untuk berpartisipasi aktif, serta memberikan ruang yang cukup bagi prakarsa, kreativitas, dan kemandirian sesuai dengan bakat, minat, kemampuan, dan perkembangan fisik serta psikologis peserta didik.

Sesuai dengan pengertian di atas, jelas bahwa proses pembelajaran adalah amanat terpenting yang menjadi jaminan standar proses satuan pendidikan yang mana harus sesuai dengan prinsip-prinsip penyelenggaraan pendidikan yaitu diselenggarakannya proses pendidikan yang menerapkan pembudayaan dan pemberdayaan peserta didik belajar sepanjang hayat. Dalam proses tersebut diperlukan guru yang mampu memberikan keteladanan, membangun kemauan, serta mengembangkan potensi dan kreatifitas peserta didik yang implikasinya adalah pergeseran paradigma proses pendidikan dari proses pengajaran ke paradigma proses pembelajaran (Rusman, 2014, hal.3).

Merujuk pada modul pelatihan guru kurikulum 2013, pedoman guru dalam proses pembelajaran yang sesuai kurikulum 2013 hasil revisi tahun 2016 adalah pemahaman yang baik atas perubahan mendasar dalam hal-hal berikut ini:

1. Proses pembelajaran yang berpusat pada peserta didik (student centered active learning).

2. Sifat pembelajaran yang kontekstual (contextual learning) dan peserta didik mencari tahu.

3. Pendekatan proses pembelajaran menggunakan pendekatan saintifik/scientific approach (walau bukan satu-satunya rujukan pendekatan/tidak diwajibkan)

4. Penilaian berbasis proses dan out put dan menggunakan penilaian otentik (autentic assesment).

Dari keempat domain revisi tersebut pembelajaran aktif merupakan pengejawantahan dari standar proses satuan pendidikan yang mengarahkan kepada guru untuk menerapkan pembelajaran yang mengaktifkan siswa, dimana pentingnya penerapan pembelajaran tersebut merupakan suatu hal yang mutlak untuk dilakukan agar pembelajaran dapat diselenggarakan 
secara optimal sebagai usaha sadar, usaha terencana, usaha untuk menciptakan suasana dan proses keaktifan, dan usaha untuk memberdayakan potensi siswa yang berkarakteristikholistik (Rusman, 2014, hlm. 388). Lebih lanjut Rusman (2014) menjelaskan bahwa penerapan pembelajaran yang mengaktifkan siswa dapat dilakukan melalui pengembangan berbagai keterampilan belajar esensial secara efektif yang antara lain sebagai berikut: (1) berkomunikasi lisan dan tertulis secara efektif, (2) berfikir kritis, logis, kritis dan kreatif, (3) rasa ingin tahu, (4) penguasaan teknologi informasi, (5) pengembangan personal dan sosial, (6) dan belajar mandiri. Enam keterampilan belajar tersebut memiliki intersepsi keterkaitan antar dimensi yang berisi pengetahuan, sikap, dan keterampilan yang sangat penting untuk terjadinya peristiwa pembelajaran yang sarat nilai dan mengembangkan potensi siswa melalui aktivitas belajar di sekolah.

Pada kenyataannya, proses pembelajaran yang merubah paradigma dari guru yang aktif menjadi siswa yang aktif masih belum terlihat dilapangan walaupun sudah tersertifikasi sebagai guru profesional, ditambah mata pelajaran PPKn masih dikenal sebagai mata pelajaran yang menjenuhkan dengan ceramah guru yang berjam-jam atau mendikte materi yang begitu panjang. Sebagaimana hasil penelitian Andi Fadllan (2010, hlm. 6) yang diterbitkan dalam Jurnal "Kreatif" IAIN Walisongo yang menyebutkan bahwa hasil kajian PMPTK Depdiknas 2012 memberikan gambaran yang jelas tentang rendahnya kompetensi yang dimiliki oleh guru khususnya mereka yang telah memperoleh sertifikat sebagai guru profesional. Menurutnya ada banyak faktor yang menyebabkan mengapa program sertifikasi ini tidak sejalan dengan peningkatan kompetensi guru dalam mengelola pembelajarannya, salah satunya adalah rendahnya komitmen dalam menerapkan pembelajaran aktif, tidak terkecuali guru mata pelajaran PPKn.

Pemahaman guru mata pelajaran PPKn dalam implementasi Kurikulum 2013 terutama yang berkaitan dengan Kompetensi Inti (KI) dan Kompetensi Dasar (KD) PPKn belum merata. Dimana secara teknis pemahaman guru tentang KI-1 sikap sosial dan KI-2 sikap spiritual masih condong berat sebelah dengan masih mengedepankan KI-3 Pengetahuan dan KI-4 ketrampilan dalam proses pembelajarannya. Domain sikap seolah terabaikan, hal tersebut bisa terlihat dalam dokumen silabus dan RPP yang berisi KI memiliki KD yang harus diturunkan dalam indikator pencapaian kompetensi (IPK) kemudian dijabarkan tujuannya dalam tujuan pembelajaran (TP) dan di praktekan pelaksanaanya dalam model-model pembelajaran, setelah itu dilaksanakan penilaian hasil belajaran, dalam hal proses pembelajaran tersebut diatas masih terbilang minim proses pembelajaran yang mencerminkan 


\section{AoEJ : Academy of Education Journal \\ Vol. 11 No 2 Tahun 2020}

pembelajaran aktif dan penggarapan domain sikap yang baik, hal tersebut dikarenakan karena belum semua guru PPKn dilatih kurikulum 2013.

Kebijakan perbaikan kurikulum 2013 akhirnya memutuskan adanya revisi dimensi kompetensi PPKn dalam hal domain pengetahuan (KD dari KI-3 dan KI-4) dimensi lebih menitikberatkan pada pemahaman pengetahuan faktual, konseptual, prosedural dan dimungkinkan sampai metakognitif dan domain keterampilan (KD dari KI-4) dengan dimensi taksonominya dari mulai berfikir tingkat rendah LOT's (Lower Order Thinking Skill's) sampai berfikir tingkat tinggi HOT's (Higher Order Thinking Skill's), psikomotorik dan berbasis pengetahuan, maka kekhawatiran tidak terciptanya pola pembelajaran aktif dalam mata pelajarn PPKn terjawab sudah. Kedua domain perubahan tersebut pada dasarnya adalah landasan proses pembelajaran aktif (active learning) yang memberdayakan peserta didik sebagai subjek belajar dan bukan lagi sebagai objek belajar dan diharapkan akan mampu meningkatkan KI-1 dan KI-2 dalam proses pembelajarannya.

Sejalan dengan revisi kebijakan Kurikulum 2013 di tahun 2016 yang memberikan perhatian lebih terhadapa aspek sikap yang dirumuskan dalam Kompetensi Inti 1 (KI-1) sikap sosial dan Kompetensi Inti 2 (KI-2) sikap spiritual, disamping aspek kognitif dan aspek psikomotor. Aspek sikap ini penting karena menurut Slameto (2013, hlm. 188) "merupakan faktor penting yang mempengaruhi hasil belajar siswa dan sikap merupakan sesuatu yang dapat dipelajari dan menentukan bagaimana individu bereaksi terhadap situasi serta menentukan apa yang dicari individu dalam kehidupan”.

Rumusan pemahaman KI Sikap tersebut merupakan kombinasi reaksi apektif, konatif (perilaku) dan kognitif, gradasi pembelajaran aktifnya meliputi tangga kompetensi yang harus dilewati siswa mulai dari kompetensi menerima, merespon/menanggapi, menghargai, menghayati dan sampai pada mengamalkan sikap spiritual dan sikap sosialnya, dengan demikian konsep pembelajaran aktif merupakan kombinasi yang baik untuk mendorong dan memprakarsai perilaku aktif belajar dengan wujud hasil belajar berupa peningkatan kompetensi sikap spiritual dan sosial siswa terutama dalam pembelajaran PPKn.

\section{KAJIAN TEORI}

\section{Pembelajaran Aktif}

Pembelajaran aktif merupakan sebuah konsep belajar dan pembelajaran yang lahir dari penelitian yang dilandasi teori-teori besar. Jika kita perhatikan sampai saat ini teori-teori belajar dan pembelajaran dalam bidang psikologi pendidikan dan filsafat pendidikan 


\section{AoEJ : Academy of Education Journal}

Vol. 11 No 2 Tahun 2020

cenderung mengelompokan dua aliran besar yaitu behaviorisme dan konstruktivisme. Alasan pokoknya adalah dari kedua aliran besar tersebut banyak dikembangkan varaian teori belajar, dengan kata lain kedua aliran tersebut banyak mempengaruhi para ahli dan pemikir pendidikan untuk mengembangkan berbagai teori dan konsep pembelajaran baru (Suyono, 2016, hlm. 55).

Hal ini, tidak terkecuali pada berekembangnya konsep pembelajaran aktif yang muncul setelah sejumlah institusi melakukan riset tentang lamanya ingatan siswa tentang materi pembelajaran terkait dengan metode pembelajaran yang dipergunakan. Hasil dari National Training Labolatories di Bethel, Maine yang ditulis oleh Miller (2005, hlm.64) Amerika Serikat menunjukan bahwa dalam kelompok pembelajaran berbasis guru (Teacher-Centerd Learning) mulai dari ceramah, tugas membaca, presentasi guru dengan audio visual dan bahkan demonstrasi, siswa hanya dapat mengingat materi pembelajaran maksimal sebesar 30\%. Dalam pembelajaran dengan metode diskusi yang tidak didominasi oleh guru (bukan diskusi kelas, whole class discussion dan guru sebagai pemimpin diskusi), siswa dapat mengingat sebanyak 50\%. Jika siswa diberi kesempatan melakukan sesuatu (doing something) mereka dapat mengingat $75 \%$. Sedangkan praktik pembelajaran belajar dengan cara mengajar (learning by teaching) menyebabkan mereka mampu mengingat sebanyak $90 \%$ materi. Hal tersebut di atas tergambar dalam kerucut pengalaman Edgar Dale seperti gambar dibawah ini:

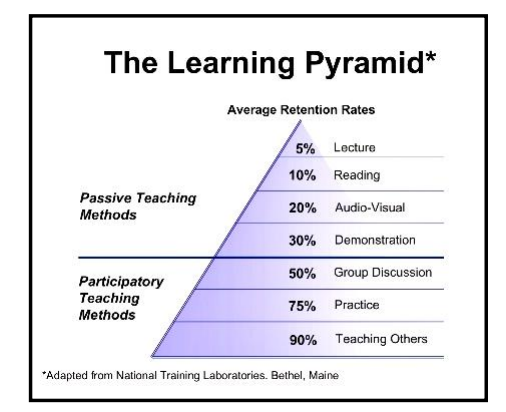

Gambar 1 Piramida Belajar

Sumber: National Training Libraries, Bethel, 1954 dikutip dalam Warsono (2013, hlm. 13).

Jika dilihat dari hasil penelitian Dale tersebut, jelaslah bahwa efektifitas pembelajaran yang selama ini banyak dilakukan guru bahkan dengan model presentasi audio video visual power point sekalipun belumlah efektif sehingga perlunya pemahaman yang mendalam konsep dan filosofi pembelajaran aktif sebagai teori pembelajaran yang harus dikuasai guru, apalagi dikaitkan dengan spirit atau ruh pembelajaran kurikulum 2013 menekankan pada pola pembelajaran berbasis aktifitas siswa (PBAS). 


\section{Objek Kajian PPKn}

Objek kajian PPKn sangatlah penting dalam konteks pembelajaran aktif di kurikulum 2013 karena objek kajian mata pelajaran ini menyangkut posisi peserta didik dalam pembelajaran. Menurut Somantri (2001) dalam Wahab dan Sapriya (2011, hlm. 316) bahwa objek kajian PKn adalah warga negara dalam hubungannya dengan organisasi kemasyarakatan, sosial, ekonomi, agama kebudayaan dan negara. Lebih lanjut Sapriya (2007) menyebutkan bahwa hakikat objek kajian PKn adalah perilaku warga negara. Hubungan antara warga negara dengan perilaku warga negara dalam konteks pengembangan kurikulum 2013 secara metodologis akan mendorong sekaligus tiga ranah proses pengembangan pembelajaran yaitu ranah sikap, pengetahuan dan keterampilan. Sebagaimana bisa disampaikan oleh Sapriya dalam lokakarya metodologi PKn tahun 1973 yang menjadi objek dan kajian PKn (dalam Wahab dan Sapriya, 2011, hlm.316) adalah menyangkut warga negara dan perilaku warga negara berupa:
a. Tingkah laku
b. Tipe pertumbuhan berfikir
c. Potensi yang ada dalam setiap diri warga negara
d. Hak dan kewajiban
e. Cita-cita dan aspirasi
f. Kesadaran (patriotisme, nasionalisme, saling pengertian internasional, moral Pancasila)
g. Usaha, kegiatan, partsipasi dan tanggungjawab.
3. Strategi dan Metode Pembelajaran PPKn

Merujuk pada strategi dan metode pembelajaran PPKn yang disebutkan dalam Lampiran III halaman 232 Permendikbud No. 59 Tahun 2014 tentang Kurikulum 2013 Sekolah Menengah Atas/Madrasah Aliyah bahwa dalam pembelajaran PPKn perlu dipahami hubungan konseptual dan fungsional strategi serta metode pembelajaran dengan pendekatan dan model pembelajaran. Pendekatan dimaknai sebagai cara menyikapi/melihat ( $a$ way of viewing). Strategi dimaknai sebagai cara mencapai tujuan dengan sukses (a way of winning the game atau a way of achieving objective). Metode adalah cara menangani sesuatu (a way of dealing), sedangkan teknik dipandan sebagai cara memperlakukan sesuatu (a way creating something). Dilain pihak model adalah kerangka yang berisikan langkah-langkah/urutanurutan kegiatan/sintakmatik yang secara operasional perlu dilakukan oleh guru dan siswa.

Lebih lanjut peraturan itu menyebutkan bahwa secara umum strategi pembelajaran dalam PPKn dimaksdudkan untuk memfasilitasi siswa dalam menguasai kompetensi secara 


\section{AoEJ : Academy of Education Journal}

Vol. 11 No 2 Tahun 2020

utuh (KI-3, KI-4, KI-3 dan KI-1) secara utuh melalui pembelajaran yang bersifat otentik. Pembelajaran PPKn dapat menggunakan strategi dan metode yang sudah dikenal selama ini seperti Jigsaw, Strategy Reading Guide (membaca buku ajar), Information Search (mencari informasi) dan sebagainya.

Menurut Wahab dan Sapriya (2011, hlm. 341) strategi pembelajaran adalah upaya untuk mencapai tujuan yang diharapkan, dengan strategi pembelajaran PPKn yang perlu dikembangkan yaitu dengan pendekatan field psychology dengan strategi pembelajaran kontinum (teaching continuum) yaitu pembelajaran yang mengkombinasikan antar sudut ekstrim inkuri dan sudut ekstrim ekspositori dengan tujuan untuk mengatasi kebosanan siswa (student centered instruction) dan kebutuan guru (teacher centered insruction). Sedangkan metode pembelajaran PPKn harus memperhatian karakteristik dan tujuan PKn yaitu metode pembelajaran yang membawa misi pendidikan demokrasi, pembangunan karakter pendidikan nilai agar menjadi warga negara yang baik dan cerdas.

4. Model-Model Pembelajaran PPKn dalam Konteks Kurikulum 2013

Secara resmi tercantum dalam buku pedoman guru PPKn yang tertulis dalam Lampiran III halaman 237 Permendikbud No. 59 Tahun 2014 tentang Kurikulum 2013 Sekolah Menengah Atas/Madrasah Aliyah bahwa macam-macam model pembelajaran PPKn harus mengacu Standar Kompetensi Lulusan dengan sasaran pembelajaran mencakup pengembangan ranah sikap, pengetahuan, dan keterampilan yang dielaborasi untuk setiap satuan pendidikan. Ketiga ranah kompetensi tersebut memiliki lintasan perolehan (proses psikologis) yang berbeda. Sikap diperoleh melalui aktivitas“ menerima, menjalankan, menghargai,menghayati, dan mengamalkan”. Pengetahuan diperoleh melalui aktivitas“ mengingat, memahami, menerapkan, menganalisis, mengevaluasi, mencipta. Keterampilan diperoleh melalu aktivitas“ mengamati, menanya, mencoba, menalar, menyaji, dan mencipta".

Adapun model-model Pembelajaran tersebut adalah:

a. Untuk memperkuat pendekatan ilmiah (scientific), perlu diterapkan pembelajaran berbasis penyingkapan/penelitian (Discovery/Inquiry Learning).

b. Untuk mendorong kemampuan peserta didik untuk menghasilkan karya kontekstual, baik individual maupun kelompok maka sangat disarankan menggunakan pendekatan pembelajaran yang menghasilkan karya berbasis pemecahan masalah (Project-Based Learning dan Problem-Based Learning). 


\section{AoEJ : Academy of Education Journal \\ Vol. 11 No 2 Tahun 2020}

Menurut Mulyasa (2015, hlm.132) pemilihan model pembelajaran hendaknya diadasarkan kepada tujuan pembelajaran, peran guru dan siswa dalam pembelajaran serta karakteristik bidang studi atau mata pelajaran, dalam pembelajaran PPKn setidaknya karakteristik pembelajaran PPKn yang lebih banyak bermuatan konten pengalaman belajar kontekstual dengan itu membutuhkan implementasi pembelajaran yang mendorong peserta didik untuk mencari dan menyingkap permasalahan sosial serta melatih keterampilan sosial melalui praktik pengalaman kewarganegaraan dengan pembelajaran berbasis masalah atau pembelajaran berbasis projek untuk menghasilkan produk belajar dalam rangka mencari solusi permasalahan sosial.

Dalam konteks pengalaman pembelajaran PPKn melalui penerapan model-model pembelajaran yang dipilih tersebut, setidaknya memiliki ciri-ciri karakteristik pembelajarang yang bermakna (meaningful), terintegrasi (integrated), berbasis nilai (value based), menantang (challenging), dan mengkatifkan karsa dan prakarya siswa (activating). Karena dengan demikian pengalaman belajar dalam model pembelajaran yang dipakai akan memfasilitasi siswa untuk membangun pengetahuan, sikap dan keterampilan kewarganegaraanya secara sendiri dan mandiri (Winataputra \& Budimansyah, 2011, hlm.134135).

\section{Penelitian Terdahulu}

Penelitian terdahulu yang dijadikan sebagai acuan dalam penelitian ini sebagai berikut:

a. Penelitian yang dilakukan oleh Nadya Putri Syailendra tahun 2014 tentang Implementasi Pendekatan Saintifik dan penilaian otentik dalam pembelajaran Pendidikan Pancasila dan Kewarganegaraan di SMAN 7 Bogor. Penelitian yang dilakukan di SMAN 7 Bogor bertujuan untuk mengetahui bagaimana penerapan pendekatan pembelajaran saintifik dan penilaian otentik dalam pembelajaran Pendidikan Pancasila dan Kewarganegaraan di SMAN 7 Bogor. Metode penelitian yang digunakan dalam penelitain tersebut adalah pendekatan kualitatif dengan metode deskriptif. Hasil penelitian menunjukan bahwa guru telah memahami langkah pendekatan saintifik dan penilaian otentik dalam pembelajaran PPKn telah dilakukan secara menyeluruh. Dalam pelaksanaan pendekatan saintifik dan penilaian otentik, guru pkn telah menunjukan langkah pendekatan saitifik dan mengolah skor menjadi nilai menggunakan format penilaian yang telah tersedia. Pendekatan saintifik dan penilaian otentik menunjukan hasil yang objektif tehadap kometensi hasil belajar siswa pada kompetensi sikap, keterampilran dan pengetahuan. 
b. Penelitian yang dilakukan oleh Camelia

Penelitian yang dilakukan oleh Camelia tahun 2014 tentang Implementasi Penilaian Otentik Dalam Menilai kompetensi Kewarganegaraan. Penelitian yang dilakukan di SMP Negeri 1 Tanjung raja bertujuan untuk memperoleh gambaran pemahaman guru, mengetahui perencanaan, mengamati guru saat melaksanakan proses penilaian dan mengkaji kegiatan guru melaporkan hasil penilaian serta memperolah gambaran Pemahaman siswa mengenai implementasi penilaian otentik dalam menilai komptensi kewarganegaraan siswa yang dilakukan guru dan tingkat ketercapaian kompetensi kewarganegaraan siswa melalui penilaian oentik. Penelitian tersebut menggunakan pendekatan kualitatif dengan metode deskriftif. Hasil penelitian menunjukan bahwa (1) Pemahaman guru mengenai penilaian otentik dalam menilai kompetensi kewarganegaraan siswa adalah cukup dengan nilai enam puluh dua. (2) Perencanaan penilaian otentik dalam menilai kompetensi kewarganegaraan yang dibuat guru belum maksimal. (3) Pelaksanaan penilaian otentik dalam menilai kompetensi kewarganegaraan yang dibuat guru belum maksimal. (4) pelaporan penilaian otentik dalam menilai kompetensi kewarganegaraan sudah dilaksanakan oleh guru kepada siswa dalam bentuk rapor semester. (5) Pemahaman siswa implementasi penilaian otentik dalam menilai komptensi kewarganegaraan siswa yang dilakukan guru cukup baik atau positif.

c. Penelitian yang dilakukan oleh Derry Nodyanto

Penelitian yang dilakukan oleh Derry Nodyanto tahun 2014 tentang Implementasi Pendekatan Saintifik dalam pembelajaran PPKn untuk meningkatkan Kecakapan Kewarganegaraan siswa. Penelitian yang dilakukan di SMA Negeri Kabupaten Bangka bertujuan untuk mengkaji implementasi penerapan pendekatan pembelajaran saintifik dalam pembelajaran PPKn untuk meningkatkan Kecakapan Kewarganegaraan siswa. Penelitian menggunakan pendekatan mixed method dengan metode deskriptif. Hasil penelitian mengungkapkan bahwa guru sudah menunjukan pemahaman yang cukup baik tentang pendekatan saintifik dan masih perlu ditingkatkan berkaitan tentang pemilihan model-model pembelajaran yang tepat sesuau dengan pendekatan saintifik. Perencanaan pembelajaran yang dibuat oleh guru umumnya sudah menggambarkan pendekatan saintifik namum belum maksimal terutama dalam kegiatan menanya. Pada proses pembelajaran dengan pendekatan saintifik sudah dilaksanakan oleh guru tetapi belum maksimal. Selain itu tidak terlihat guru menggunakan media pembelajaran serta 


\section{AoEJ : Academy of Education Journal}

Vol. 11 No 2 Tahun 2020

penilaian. Selanjutnya penerapan pendekatan saintifik menunjukan perubahan yang cukup baik terhadap kecakapan kewarganegaraan siswa yang meliputi intelectual skill dan participation skill.

Ketiga penelitian terdahulu tersebut di atas masih terfokus pada hal khusus dalam kaitannya dengan implementasi pendekatan saintifik dan penilaian otentik. Padahal pemahaman tentang hal umum dari implementasi kurikulum 2013 harus dipahami dan diteliti dengan seksama terlebih dahulu terutama mengenai pembelajaran aktif karena secara jelas disebutkan sebagai ruh kurilulum 2013. Dengan demikian pendekatan saitifik dan penilaian otentik grand theory-nya adalah active learning yaitu pembelajaran yang mengaktifkan siswa. Berdasar hal tersebut di atas posisi peneliti dalam penelitian ini adalah berada didepan pada upaya menemukan jawaban tentang pemahaman, perencanaan, pelaksanaan dan dampak pembelajaran aktif sebagai modal awal pemahaman dan pelaksanaan pendekatan saintifik dan penilaian otentik yang dilakukan guru.

Kesamaan objeknya adalah sekolah dan subjek penelitian yaitu guru dan siswa namun perbedaanya terdapat pada pemahaan umum guru dan siswa terhadap teori terdepan pelaksanaan kurikulum 2013. Dengan demikian arahnya kepada pemahaman umum guru dan sekolah terhadap inti falsafah pengembangan kurikulum yang dilaksanakan sehingga kedepan dengan telah terpenuhinya pemahaman tersebut akan mendorong guru untuk mampu mengembangkan model, strategi, pendekatan dan metode baru dalam pembelajaran kurikulum 2013.

\section{METODE PENELITIAN}

Metode yang digunakan dalam penelitian ini adalah metode deskriptif, dimana penelitian tersebut berusaha mendeskripsikan peristiwa dan kejadian yang menjadi pusat perhatian penelitian ini. Menurut Nazir (2005, hlm. 54) Metode deskriptif adalah suatu metode dalam meneliti status sekelompok manusia, suatu obyek, suatu set kondisi, suatu sistem pemikiran, ataupun suatu kelas peristiwa pada masa sekarang. Tujuan dari penelitian deskriptif ini adalah untuk membuat deskripsi, gambaran atau lukisan secara sistematis, faktual dan akurat mengenai fakta-fakta, sifat-sifat hubungan antarfenomena yang diselidiki.

Pada penelitian ini metode deskriptif tersebut akan berusaha memberikan gambaran yang objektif dan sistematis mengenai implementasi pembelajaran aktif (active learning) untuk meningkatkan kompetensi sikap spiritual dan sosial dalam pembelajaran Pendidikan Pancasila dan Kewarganegaraan karena merupakan suatu hal atau permasalahan yang terjadi 
pada saat ini di sekolah-sekolah yang menerapkan sistem kurikulum 2013 dalam pelaksanaan pembelajarannya. Jadi hasil analisis dari penelitian yang akan dilaksanakan adalah berupa pemaparan mengenai hal yang diteliti dengan bentuk uraian naratif.

Penelitian ini berlokasi di SMK Negeri Pancatengah, tepatnya di Kampung Paseh Desa Jayamukti, kecamatan Pancatengah, Kabupaten Tasikmalaya. Alasan pemilihan tempat ini sebagai subjek penelitian karena merupakan sekolah sasaran pelaksanaan Kurikulum 2013 yang mana semenjak berdirinya dari tahun 2009 belum ada penelitian tentang proses pembelajaran terutama terkait hal-hal implementasi pembelajaran aktif dan hal yang berkaitan dengan kompetensi sikap spiritual dan sikap sosial.

Subjek penelitian adalah guru mata pelajaran PPKn, siswa kelas X dan komponen sekolah yang diwakili oleh Wakil kepala sekolah bidang kurikulum SMK Negeri Pancatengah. Jadi dalam penelitian ini, peneliti tidak mengambil secara keseluruhan komponen-komponen sekolah di SMK Negeri Pancatengah. Selanjutnya penelitian ini hanya dibatasi hanya hal-hal yang terkait proses pembelajaran aktif dalam mata pelajaran Pendidikan Pancasila dan Kewarganegaraan.

\section{PEMBAHASAN}

Berikut disajikan uraiannya dengan berdasarkan pada fokus kajian penelitian yakni:

1. Pemahaman Guru, Kepala Sekolah dan Wakil Kepala Sekolah Mengenai Implementasi Pembelajaran Aktif untuk Meningkatkan Kompetensi Spiritual dan Sosial Siswa dalam Pembelajaran Pendidikan Pancasila dan Kewarganegaraan, adalah berikut ini:

Tabel 1 Triangulasi Sumber Menganai Bagaimana Pemahaman Guru Mengenai Implementasi Pembelajaran Aktif (Active Learning) untuk Meningkatkan Kompetensi Spiritual dan Sosial Siswa dalam Pembelajaran PPKn

\begin{tabular}{|c|c|c|c|}
\hline \multirow[b]{2}{*}{ Rumusan Masalah } & \multicolumn{3}{|c|}{ Triangulasi Sumber } \\
\hline & $\begin{array}{l}\text { Wakasek } \\
\text { Kurikulum }\end{array}$ & Kepala Sekolah & Guru PPKn \\
\hline $\begin{array}{l}\text { Bagaimana Pemahaman } \\
\text { guru, kepala sekolah dan } \\
\text { wakil kepala sekolah } \\
\text { mengenai implementasi } \\
\text { pembelajaran aktif } \\
\text { (active learning) untuk } \\
\text { meningkatkan } \\
\text { kompetensi spiritual dan } \\
\text { sosial siswa dalam } \\
\text { pembelajaran Pendidikan }\end{array}$ & $\begin{array}{l}\text { Pembelajaran aktif } \\
\text { adalah itu adalah } \\
\text { pelaksanaan } \\
\text { belajar dimana } \\
\text { guru tidak } \\
\text { mendominasi } \\
\text { proses } \\
\text { pembelajaran } \\
\text { melainkan siswa- } \\
\text { lah yang }\end{array}$ & $\begin{array}{l}\text { Pembelajaran aktif } \\
\text { adalah ruh dari K- } \\
13 \text { yang terasa } \\
\text { manfaatnya } \\
\text { terutama pada } \\
\text { siswa yang terlihat } \\
\text { belajar tidak } \\
\text { seperti biasanya, } \\
\text { pembelajaran } \\
\text { banyak di }\end{array}$ & $\begin{array}{l}\text { Pembelajaran aktif } \\
\text { itu adalah suatu } \\
\text { pembelajaran } \\
\text { dimana siswa lebih } \\
\text { aktif dalam } \\
\text { mendominasi proses } \\
\text { pembelajaran, } \\
\text { misalnya siswa } \\
\text { diharapkan mampu } \\
\text { untuk memgamati, }\end{array}$ \\
\hline
\end{tabular}




\begin{tabular}{|c|c|c|c|}
\hline $\begin{array}{l}\text { Pancasila dan } \\
\text { Kewarganegaraan }\end{array}$ & $\begin{array}{l}\text { menentukan } \\
\text { sendiri jalannya } \\
\text { proses belajar } \\
\text { karena secara } \\
\text { secara realita } \\
\text { masing masing } \\
\text { siswa mempunyai } \\
\text { cara belajarnya } \\
\text { sendiri-sendiri dan } \\
\text { itu artinya berbeda } \\
\text { satu sama lainnya. }\end{array}$ & $\begin{array}{l}\text { dominasi siswa. } \\
\text { Guru berperan } \\
\text { sebagai fasilitator } \\
\text { belajar. }\end{array}$ & $\begin{array}{l}\text { menanya, mencoba, } \\
\text { mengasosiasi } \\
\text { kemudian } \\
\text { mengkomunikasikan } \\
\text { mengenai apa yang } \\
\text { menjadi materi } \\
\text { dalam pembelajaran }\end{array}$ \\
\hline
\end{tabular}

Sumber: olah data penulis, 2016.

Berdasar kepada pendapat secara umum dari wakasek kurikulum, kepala sekolah dan guru PPKn tersebut di atas untuk menjawab pertanyaan penelitian tentang bagaimana pemahaman guru mengenai pembelajaran aktif, peneliti akan memaparkan kembali kajian teoritik mengenai pengertian pembelajaran aktif dan pengertian komptensi sikap dalam pembelajaran. Pendapat guru mengenai Pemahaman Guru Mengenai Implementasi Pembelajaran Aktif (Active Learning) untuk meningkatkan kompetensi spiritual dan sosial siswa dalam pembelajaran PPKn, dapat diambil kesimpulan sementara bahwa kepala sekolah, guru PPKn, Guru PAI dan Wakil kepala sekolah bidang kurikulum pada umumnya sudah memahami pembelajaran aktif dapat meningkatkan kompetensi spiritual dan sosial siswa.

2. Persiapan dan Perencanaan Guru PPKn dalam Pelaksanaan Pembelajaran Aktif untuk

Meningkatkan Kompetensi Spiritual dan Sosial Siswa, adalah sebagai berikut:

Tabel 2 Triangulasi Teknik mengenai Bagaimana Perencanaan guru dalam Implementasi Pembelajaran Aktif (Active Learning) untuk Meningkatkan Kompetensi Spiritual dan Sosial Siswa dalam Pembelajaran PPKn

\begin{tabular}{|l|l|l|l|}
\hline \multirow{2}{*}{\multicolumn{1}{|c|}{ Rumusan Masalah }} & \multicolumn{3}{|c|}{ Triangulasi Teknik } \\
\cline { 2 - 4 } Bagaimana Perencanaan & \multicolumn{1}{|c|}{ Wawancara } & \multicolumn{1}{|c|}{ Observasi } & Dokumentasi \\
guru dalam Implementasi & mempersiapkan & Pencana & Berdasarkan RPP \\
Pembelajaran Aktif (Active & diri dengan & Pembelajaran & yang diamati, \\
Learning) untuk & membuat rencana & dilakukan oleh & Pembelajaran \\
Meningkatkan Kompetensi & pelaksanaan & guru disertai & Aktif (Active \\
Spiritual Dan Sosial Siswa & pembelajaran & dengan instrument & Learning) dalam \\
Dalam Pembelajaran PPKn & RPP) dengan & penilaiannya & pembelajaran \\
& menyesuaikan & Yang disesuai & PPKn ditulis \\
& pendekatan dan & dengan tuntutan & secara lengkap, \\
& model & setiap KD/materi & rapi dan mendetail \\
& pembelajaran apa & pokok pelajaran. & disertai format \\
& yang akan & & penilaian yang \\
\hline
\end{tabular}




\begin{tabular}{|l|l|l|l|}
\hline & $\begin{array}{l}\text { diterapkan karena } \\
\text { setip KD berbeda } \\
\text { tuntutan keaktifan } \\
\text { siswanya. }\end{array}$ & & lengkap. \\
\hline
\end{tabular}

Sumber: olah data penulis, 2016.

Perencanaan pelaksanaan pembelajaran adalah satu kewajiban guru dalam tugasnya sebagai pendidik karena tugas pendidik menurut Undang-Undang Nomor 20 Tahun 2003 tentang Sistem Pendidikan Nasional (SISDIKNAS) Bab XI pasal 39 ayat 2 dinyatakan bahwa: "Pendidik merupakan tenaga profesional yang bertugas merencanakan dan melaksanakan proses pembelajaran, menilai hasil pembelajaran, melakukan pembimbingan dan pelatihan, serta melakukan penelitian”. Kemudian dipertegas kembali dalam Permendikbud nomor 22 Tahun 2016 tentang Standar Proses Pendidikan Dasar dan Menengah bahwa:

Setiap pendidik pada satuan pendidikan berkewajiban menyusun RPP secara lengkap dan sistematis agar pembelajaran berlangsung secara interaktif ,inspiratif, menyenangkan, menantang, efisien, memotivasi peserta didik untuk berpartisipasi aktif, serta memberikan ruang yang cukup bagi prakarsa, kreativitas, dan kemandirian sesuai dengan bakat, minat, danperkembangan fisik serta psikologis peserta didik. RPP disusun berdasarkan KD atau subtema yang dilaksanakan satu kali pertemuan atau lebih.

Kewajiban menyusun RPP bukannya tanpa alasan karena hal tersebut berfungsi sebagai panduan mengajar guru dan sekaligus panduan belajar siswa, sebagaimana menurut Hamzah B. Uno (2010, hal. 84-85) kenapa RPP diperlukan dibuat oleh guru karena "dasar perlunya perencanaan pembelajaran adalah agar dapat tercapainya perbaikan pembelajaran karena dengan merencanakan atau mendesain pembelajaran artinya guru berupaya untuk membelajarkan siswa itulah sebabnya dalam belajar siswa tidak hanya berinteraksi dengan guru sebagai salah satu sumber belajar melainakan berinterkasi dengan keseluruhan sumber belajar".

Merujuk pada pedoman umum pembuatan RPP tersebut di atas guru dituntut untuk lebih fleksibel, kreatif dan inovatif dalam mendesain rencana pembelajaran apalagi dinamika perubahan K-13 melalui revisi yang terus menerus membuat guru harus lebih cekatan merespon perubahan tersebut.

Berdasarkan hasil temuan dan merujuk pada teori-teori tersebut dapatlah terjawab bahwa model, strategi dan metode pembelajaran haruslah dikuasai guru dalam menyusun RPP dengan langkah-langkah pembelajaran harus tuntas dilaksanakan walaupun dalam pelaksanaanya tidaklah harus selalu urut. 
3. Pelaksanaan Pembelajaran Aktif (Active Learning) untuk Meningkatkan Kompetensi Spiritual dan Sosial Siswa dalam Pembelajaran Pendidikan Pancasila dan Kewarganegaraan (PPKn), adalah sebagai berikut:

Tabel 3 Triangulasi Teknik mengenai Pelaksanaan Pembelajaran guru dalam Implementasi Pembelajaran Aktif (Active Learning) untuk Meningkatkan Kompetensi Spiritual dan Sosial Siswa dalam Pembelajaran PPKn

\begin{tabular}{|c|c|c|c|}
\hline \multirow[b]{2}{*}{ Rumusan Masalah } & \multicolumn{3}{|c|}{ Triangulasi Teknik } \\
\hline & Wawancara & Observasi & Dokumentasi \\
\hline $\begin{array}{l}\text { Bagaimana Pelaksanaan } \\
\text { guru dalam Implementasi } \\
\text { Pembelajaran Aktif } \\
\text { (Active Learning) untuk } \\
\text { Meningkatkan } \\
\text { Kompetensi Spiritual } \\
\text { Dan Sosial Siswa Dalam } \\
\text { Pembelajaran PPKn }\end{array}$ & $\begin{array}{l}\text { Pelaksanaan } \\
\text { pembelajaran aktif } \\
\text { yang dilaksanakan } \\
\text { oleh guru PPKn } \\
\text { tersebut adalah } \\
\text { dengan } \\
\text { mengimplementasikan } \\
\text { model pembelajaran, } \\
\text { project based learning } \\
\text { (PjBL), Inquiry } \\
\text { learning, discovery } \\
\text { learning dan problem } \\
\text { based leraning (PBL), } \\
\text { model model tersebut } \\
\text { digunakan dengan } \\
\text { alasan utama yaitu } \\
\text { karena itu yang } \\
\text { diajarkan pada saat } \\
\text { workshop/pelatihan } \\
\text { implementasi K-13 } \\
\text { dan memang yang } \\
\text { paling mudah } \\
\text { menjalankannya di } \\
\text { kelas. }\end{array}$ & $\begin{array}{l}\text { Pelaksanaan } \\
\text { pembelajaran aktif } \\
\text { dengan } \\
\text { menggunakan } \\
\text { model } \\
\text { pembelajaran yang } \\
\text { dipakai sesuai } \\
\text { dengan RPP } \\
\text { namun masih } \\
\text { terkendala } \\
\text { pengaturan waktu, } \\
\text { control kelas jadi } \\
\text { berkurang, kadang } \\
\text { Peserta didik tidak } \\
\text { melakukan apa } \\
\text { yang diinginkan } \\
\text { guru dan pernah } \\
\text { terlihat peserta } \\
\text { didik erkesanikut- } \\
\text { ikutan dalam } \\
\text { mengerjakan tugas }\end{array}$ & $\begin{array}{l}\text { Berdasarkan } \\
\text { dokumen RPP } \\
\text { yang diamati, } \\
\text { pelaksanaan } \\
\text { Pembelajaran } \\
\text { Aktif (Active } \\
\text { Learning) dalam } \\
\text { pembelajaran } \\
\text { PPKn dilakukan } \\
\text { sesuai langkah } \\
\text { model } \\
\text { pembelajaran yang } \\
\text { digunakan. }\end{array}$ \\
\hline
\end{tabular}

Sumber: olah data penulis, 2016.

Dalam kegiatan pendahuluan urutan langkahnya cukup sistematis namun terkesan panjang dan membutuhkan waktu. Itu disebabkan amanat kurikulum 2013 yang harus menyisipkan muatan penanaman nasionalisme dengan menyanyikan lagu wajib nasional, penanaman pembudayaan membaca dengan membaca buku selama kurang lebih 10 menit disamping kegiatan apersepsi, absensi dan motivasi belajar. Pengamatan peneliti, dalam hal ini guru memerlukan keterampilan dalam membuka pelajaran. 
Selanjutnya dalam kegiatan inti pembelajaran yang merupakan penerapan sintak atau langkah model pembelajaran yang dipakai peneliti melihat ada kegiatan yang sistematis dilaksanakan oleh guru. Prinsipnya dalam kegiatan inti pembelajaran menurut Mulyasa (2010, hlm. 181) adalah kegiatan inti pembelajaran, merupakan kegiatan utama untuk menanamkan, mengembangkan pengetahuan, sikap dan ketrampilan berkaitan dengan bahan kajian yang bersangkutan. Kegiatan inti mencakup beberapa kegiatan antara laian: penyampaian tujuan pembelajaran; menyampaian materi dengan menguggunakan metode, alat, media, yang sesuai; memberikan bimbingan bagi pemahaman siswa; melakukan pengecekan tentang pemahaman siswa. Langkah model pembelajaran yang digunakan dilaksanakan dengan baik walaupun urutannya tidak harus selalu berurutan. Hal tersebut sesuai dengan pedoman implementasi K-13 (Kemendikbud, 2016) bahwa langkah-langkah pendekatan saintifik yang pasti ada dalam model pembelajaran terlebih pada pembelajaran tematik terapadu walaupun urutan langkahnya tidak harus selalu dilalui secara berurutan.

Pada kegiatan penutup, peneliti menilai hal yang kurang terlaksana dengan baik adalah rencana tindak lanjut dari kesimpulan pembelajaran, umpan balik dan evaluasi yang kadang tidak tersampaiakan karena siswa sudah lelah dalam kegiatan inti.

Namun setidaknya dalam kegiatan penutup guru harus berusaha untuk menutup pelajaran dengan baik, menurut Marno (2010, hlm. 90) dalam menutup pelajaran guru harus:

a. Merangkum atau meringkas inti pokok pelajaran

b. Memberikan dorongan psikologi atau sosial kepada siswa

c. Memberi petunjuk tindak lanjut topic selanjutnya

d. Mengadakan evaluasi tenatang pelajaran yang baru selesai

Catatan penting sebagi pendukung dalam penerapan model-model pembelajaran aktif adalah bahwa model tersebut sangat berpengaruh pada hasil belajar yang dicapai hal tersebut dibuktikan oleh hasil penelitian Bekti Wulandari (2017, hlm.178). yang dipulikasikan dalam jurnal Jurnal Pendidikan Vokasi UNY yang membuat kesimpulan bahwa terdapat perbedaan hasil belajar antara siswa yang diajar dengan metode PBL/Problem Based Learning dengan yang diajar dengan metode demonstrasi ditinjau dari motivasi tinggi dan rendah.

Berdasarkan hasil temuan dan merujuk pada teori-teori tersebut dapat diambil kesimpulan sementara bahwa pelaksanaan pembelajaran aktif dalam pembelajaran PPKn dilaksanakan dengan baik dengan mengikuti langkah-langkah pembelajaran aktif sesuai dengan model yang direncanakan namun masih terkendala pengaturan waktu. 
4. Faktor Pendukung dan Kendala dalam Implementasi Pembelajaran Aktif (Active Learning) untuk Meningkatkan Kompetensi Spiritual dan Sosial Siswa dalam

Pembelajaran Pendidikan Pancasila dan Kewarganegaraan, adalah sebagai berikut:

Tabel 4 Triangulasi Teknik mengenai apa saja faktor pendukung dan kendala dalam implementasi pembelajaran aktif (active learning) untuk meningkatkan kompetensi spiritual dan sosial siswa dalam pembelajaran PPKn

\begin{tabular}{|c|c|c|c|}
\hline \multirow[b]{2}{*}{ Rumusan Masalah } & \multicolumn{3}{|c|}{ Triangulasi Sumber } \\
\hline & $\begin{array}{c}\text { Wakasek } \\
\text { Kurikulum }\end{array}$ & Kepala Sekolah & Guru PPKn \\
\hline $\begin{array}{l}\text { Apa saja faktor pendukung } \\
\text { dan kendala dalam } \\
\text { implementasi pembelajaran } \\
\text { aktif (active learning) untuk } \\
\text { meningkatkan kompetensi } \\
\text { spiritual dan sosial siswa } \\
\text { dalam pembelajaran PPKn }\end{array}$ & $\begin{array}{l}\text { Pembelajaran aktif } \\
\text { dapat } \\
\text { dilaksanakan oleh } \\
\text { guru karena } \\
\text { sebagain besar } \\
\text { guru sudah faham } \\
\text { metode dan model } \\
\text { pembelajarannya } \\
\text { namun masih } \\
\text { memiliki kendala } \\
\text { dalam beberapa } \\
\text { hal sperti daya } \\
\text { dukung buku dan } \\
\text { peralatan belajar. }\end{array}$ & $\begin{array}{l}\text { Pembelajaran aktif } \\
\text { mudah untuk } \\
\text { dilaksanakan oleh } \\
\text { guru karena daya } \\
\text { dukung } \\
\text { pemerintah dan } \\
\text { kebijakan } \\
\text { penerapan K-13 } \\
\text { tantangannya } \\
\text { adalah keajegan } \\
\text { guru dalam } \\
\text { melaksanakannya, } \\
\text { sarana belajar } \\
\text { yang masih terus } \\
\text { dibenahi dan } \\
\text { bahan ajar yang } \\
\text { terus ditambah. }\end{array}$ & $\begin{array}{l}\text { Pembelajaran aktif } \\
\text { bisa dilaksakan } \\
\text { karena didukung } \\
\text { oleg guru yang } \\
\text { sudah di training } \\
\text { dan mempelajari } \\
\text { model } \\
\text { pembelajaran aktif } \\
\text { sedangkan } \\
\text { tantangannya } \\
\text { adalah keajegan } \\
\text { guru } \\
\text { melaksanakannya, } \\
\text { pengelolaan waktu } \\
\text { belajar dan sarana } \\
\text { prasarana }\end{array}$ \\
\hline
\end{tabular}

Berikutnya akan dibahas bagaimana faktor pendukung dan kendala akan mempengaruhi pembelajaran aktif dilaksanakan oleh guru:

Dalam pelaksanaan pembelajaran pendidikan, pemerintah mengacu pada Undang Undang Sistem Pendidikan Nasional No. 20 tahun 2003 Bab XII Pasal 45 tentang Sarana dan Prasarana Pendidikan berbunyi:

(1) Setiap satuan pendidikan formal dan nonformal menyediakan sarana dan prasarana yang memenuhi keperluan pendidikan sesuai dengan pertumbuhan dan perkembangan potensi fisik, kecerdasan intelektual, sosial, emosional, dan kejiwaan peserta didik. (2) Ketentuan mengenai penyediaan sarana dan prasarana pendidikan pada semua satuan pendidikan sebagaimana dimaksud pada ayat (1) diatur lebih lanjut dengan peraturan pemerintah.

Kemudian dipertegas oleh peraturan pemerintah No. 24 tahun 2007 tentang standar sarana dan prasarana yang disempunakan oleh PP No.19 tahun 2005 tentang standar nasional pendidikan merupakan standar nasional pendidikan yang berkaitan dengan kriteria minimal 


\section{AoEJ : Academy of Education Journal}

Vol. 11 No 2 Tahun 2020

tentang ruang belajar, tempat berolahraga, tempat beribadah, perpustakaan, laboratorium, bengkel kerja, tempat bermain, tempat berkreasi dan berekreasi, serta sumber belajar lain, yang diperlukan untuk menunjang proses pembelajaran, termasuk penggunaan teknologi informasi dan komunikasi. Sarana belajar yang memadai akan sangat mendukung proses pembelajaran dan mutu pendidikan secara umum. Mulyasa (2005, hlm. 3) menjelaskan bahwa: "agar pembangunan pendidikan dapat berkontribusi terhadap kualitas sumber daya manusia terdapat tiga syarat utama yang harus diperhatikan yaitu: sarana gedung, buku yang memadai dan guru yang berkualitas" dari ketiga hal yang disebutkan Mulyasa ketiga sangat berperan dalam penciptaan kondisi belajar peserta didik. Pembelajaran akan timpang jika salah satu diantaranya belum tersedia.

Penelitian terkait yang dilakukan oleh Jumaidi Nur (2015, hal. 8) yang diterbitkan dalam jurnal Cemerlang Volume III, Nomor1, Juni 2015 tentang pengaruh sarana tergadap minat belajar siswa membuktikan jika sarana belajar siswa semakin ditingkatkan maka minat belajar siswa akan meningkat dapat diterima karena telah terbukti kebenarannya.

Berdasarkan hasil temuan dan merujuk pada teori-teori tersebut dapat terjawab apa saja faktor pendukung implementasi pembelajaran aktif dalam pembelajaran PPKn yaitu sarana dan prasarana yang belum memadai, keajegan guru, dan kualitas guru sangat berpengaruh namun tidak merupakan hal yang siginifikan pengaruhnya.

5. Dampak Implementasi Pembelajaran Aktif Terhadap Peningkatan Kompetensi Spiritual dan Sosial Siswa dalam PPKn

Hasil yang didapatkan dari penerapan pembelajaran aktif terhadap peningkatan kompetensi spiritual dan sosial siswa dalam pembelajaran Pendidikan Pancasila dan Kewarganegaraan (PPKn) di SMK Negeri Pancatengah terlihat dari hasil wawancara peneliti dengan guru PPKn, Siswa dan Waka Kurikulum ditambah dengan pengamatan langsung terhadap proses pembelajaran serta melihat hasil penilaian sikap spiritual dan sosial siswa. Rangkuman hasil wawancaranya sebagai berikut:

Hasil secara signifikan belum terlihat jelas dari pelaksanaan proses pembelajaran aktif dalam upaya meningkatkan komptensi spiritual dan sosial siswa, namun jika dibanding dengan kelas XI yang belum melaksanakan prinsip pembelajaran aktif terjadi perubahan yang lebih baik pada hasil penilaian sikap spiritual dan sosial dalam pembelajarannya. Seperti terlihat jelas dalam perubahan sikap menghargai orang lain, pandai bersyukur, lebih kritis dan mendorong siswa untuk mandiri dan mampu mencari dan menemukan pengetahuannya sendiri melalui aktifitas belajarnya. 
Penelitian sejenis yang dilakukan oleh Ramli Abdullah yang diterbitkan dalam Jurnal Ilmiah DIDAKTIKA Februari 2012 VOL. XII NO. 2, 216-231 juga membuktikan bahwa pembelajaran yang menekankan pada aktifitas siswa memberikan beberapa keuntungan kepada peserta didik, seperti: (1)Memungkinkan untuk menemukan bakat terpendam pada diri sesorang yang selama ini tidak tampak, (2) Memungkinkan pembelajaran berlangsung terus menerus dan belajar menjadi mudah diserap dan lebih siap diterapkan, dan (3) Seseorang dapat belajar sesuai dengan kecepatan dan dengan waktnya yang tersedia.

Tabel 5 Triangulasi sumber bagaimana hasil implementasi pembelajaran aktif untuk meningkatkan kompetensi spiritual dan sosial siswa dalam pembelajaran PPKn.

\begin{tabular}{|c|c|c|c|}
\hline \multirow[b]{2}{*}{ Rumusan Masalah } & \multicolumn{3}{|c|}{ Triangulasi Sumber } \\
\hline & $\begin{array}{l}\text { Wakasek } \\
\text { Kurikulum }\end{array}$ & Siswa & Guru PPKn \\
\hline $\begin{array}{l}\text { Dampak implementasi } \\
\text { pembelajaran aktif terhadap } \\
\text { peningkatan kompetensi } \\
\text { spiritual dan sosial siswa dalam } \\
\text { pembelajaran Pendidikan } \\
\text { Pancasila dan } \\
\text { Kewarganegaraan (PPKn) }\end{array}$ & $\begin{array}{l}\text { Pembelajaran aktif } \\
\text { Memberi dampak } \\
\text { pada terjadinya } \\
\text { perbahan sikap } \\
\text { menghargai orang } \\
\text { lain, pandai } \\
\text { bersyukur, lebih } \\
\text { kritis dan } \\
\text { mendorong siswa } \\
\text { untuk mandiri dan } \\
\text { mencari } \\
\text { pengetahuan tanpa } \\
\text { panduan guru. } \\
\text { Pencapaian hasil } \\
\text { maksimal untuk } \\
\text { penilaian KI-1 dan } \\
\text { KI-2 cukup } \\
\text { tercapai }\end{array}$ & $\begin{array}{l}\text { Pembelajaran aktif } \\
\text { membawa hasil } \\
\text { pada perubahan } \\
\text { sikap menghargai } \\
\text { orang lain, pandai } \\
\text { bersyukur, lebih } \\
\text { kritis dan } \\
\text { mendorong siswa } \\
\text { untuk mandiri dan } \\
\text { mampu mencari } \\
\text { dan menemukan } \\
\text { pengetahuannya } \\
\text { sendiri melalui } \\
\text { aktifitas } \\
\text { belajarnya }\end{array}$ & $\begin{array}{l}\text { Pembelajaran aktif } \\
\text { memberi dampak } \\
\text { terhadap } \\
\text { perubahan sikap } \\
\text { menghargai orang } \\
\text { lain, pandai } \\
\text { bersyukur, lebih } \\
\text { kritis dan } \\
\text { mendorong siswa } \\
\text { untuk mandiri dan } \\
\text { mampu mencari } \\
\text { dan menemukan } \\
\text { pengetahuannya } \\
\text { sendiri melalui } \\
\text { aktifitas } \\
\text { belajarnya dan } \\
\text { mendorong siswa } \\
\text { untuk berfikir } \\
\text { tingkat tinggi. }\end{array}$ \\
\hline
\end{tabular}

Sumber: olah data penulis, 2016

Untuk membahas hasil temuan penelitian di tersebut diatas, peneliti merujuk pada Undang-undang Sisdiknas No. 20 Tahun 2013 Pasal 3 yang menyakatan bahwa:

Pendidikan nasional berfungsi mengembangkan kemampuan dan membentuk watak serta peradaban bangsa yang bermartabat dalam rangka mencerdaskan kehidupan bangsa, bertujuan untuk berkembangnya potensi peserta didik agar menjadi manusia yang beriman dan bertakwa kepada Tuhan Yang Maha Esa, berakhlak mulia, sehat, berilmu,cakap, kreatif, mandiri, dan menjadi warga negara yang demokratis serta bertanggungjawab. 
Hal tersebut di atas dikuatkan oleh pendapat Broom dalam Made Pidarta (2000, hlm. 171), fungsi pendidikan adalah: 1). transmisi budaya meningkatkan integrasi sosial atau masyarakat, 2). mengadakan seleksi dan alokasi tenaga kerja melalui pendidikan itu sendiri, 4). dan mengembangkan kepribadian.

Sedangkan menurut Menurut David Popenoe (1971) dalam Maryati (2007, hlm. 73-74), ada empat macam fungsi pendidikan: 1). Transmisi (pemindahan) kebudayaan masyarakat. 2) Memilih dan mengajarkan peranan sosial.3). Sekolah mengajarkan corak kepribadian. 4). Sumber inovasi sosial.

Dari beberapa paparan fungsi pendidikan tersebut diatas maka diterjemahkan bahwa dampak pembelajaran yang mendorong siswa untuk aktif dalam belajarnya akan mampu mengembangkan karakter, kepribadian baik dan mampu menjadi insan sosial yang baik.

Berdasarkan deskripsi dan pembahasan dapat diambil kesimpulan sementara sebagai berikut: hasil dari implementasi pembelajaran aktif dalam pembelajaran PPKn menunjukan terjadinya perubahan sikap positif siswa, lebih mampu bersyukur atas kemampuan dirinya, mampu belajar dengan baik dan antusias, mampu bekerjasama dalam belajar dan mampu mencari serta menemukan pengetahuan dalam belajarnya. Walaupun hasil yang terlihat muncul belum begitu nampak signifikan namun menunjukan kecenderungan peningkatan yang lebih baik.

\section{SIMPULAN}

Merujuk pada pembahasan, maka secara umum dapat disimpulkan bahwa implementasi pembelajaran aktif dalam pembelajaran PPKn untuk meningkatkan kompetensi sikap sosial dan spiritual siswa merupakan suatu keniscayaan. Proses pembelajaran PPKn dengan menggunakan model-model pembelajaran aktif dapat menunjukan terjadinya perubahan sikap positif siswa, mampu mendorong siswa meningkatkan kemampuan dirinya, mampu belajar dengan baik dan antusias, mampu bekerjasama, mencari serta menemukan pengetahuan dalam belajarnya.

Simpulan secara khusus dalam penelitian ini dapat dirumuskan sebagai berikut:

a. Pemahaman guru terhadap konsep model dan strategi pembelajaran aktif dalam pembelajaran PPKn telah cukup baik. Namun pada tataran implementasinya di kelas pembelajaran aktif diterjemahkan oleh guru sebagai sebuah proses yang mengacu pada model-model pembelajaran yang disarankan dalam kurikulum 2013 dan model pembelajaran lain yang didapatkan guru dari buku atau dari teori belajar yang kemudian 


\section{AoEJ : Academy of Education Journal}

Vol. 11 No 2 Tahun 2020

implikasinya akan mampu meningkatkan kompetensi sikap, pengetahuan dan keterampilan peserta didik.

b. Perencanaan pembelajaran dengan menggunakan model pembelajaran aktif dilakukan secara rapih, sistematis dan mendetail, langkah-langkah model yang akan dilaksanakan dicantumkan dalam tahapan inti pembelajaran dengan jelas. Penilaian pembelajarannya dilampirkan dengan lengkap disusun berdasarkan pedoman penilaian, rubrik, dan jurnal yang digunakan guru untuk melakukan penilaian melalui observasi langsung dan penilaian antar teman.

c. Pelaksanaan pembelajaran aktif

Pelaksanaan pembelajaran aktif dalam pembelajaran PPKn, guru PPKn telah menunjukkan pelaksanaan langkah-langkah model pembelajaran aktif yang digunakannya dan model pembelajaran yang digunakan diantaranya adalah: yaitu model pembelajaran berbasis masalah atau problem based learning/PBL, Inquiry Learning, Discovery learning, dan pembelajaran berbasis proyek atau project based learning/PjBL. Pemakaian model pembelajaran tersebut ternyata telah mampu menciptakan proses pembelajaran yang interaktif, menyenangkan, menantang, inspiratif, memotivasi peserta didik untuk berpartisipasi aktif, serta memberikan ruang yang cukup bagi prakarsa, kreativitas, dan kemandirian sesuai dengan bakat, minat, kemampuan, dan perkembangan fisik peserta didik. Walaupun masih ditemukan kendala dalam pengelolaan waktu efektif belajar serta presentase keaktifan guru dalam proses pembelajarannya.

d. Faktor pendukung dan tantangan pelaksanaan pembelajaran aktif

Faktor pendukung pembelajaran aktif karena adanya daya dukung pemerintah dan kebijakan penerapan K-13 dan sebagain besar guru sudah faham metode dan model pembelajarannya namun masih memiliki kendala dalam beberapa hal lain sperti daya dukung buku dan peralatan belajar dengan tantangannya dan juga keajegan guru dalam melaksanakannya.

e. Hasil pelaksanaan pembelajaran aktif

Memberi dampak pada terjadinya perbahan sikap menghargai orang lain, pandai bersyukur, lebih kritis dan mendorong siswa untuk mandiri dan mencari pengetahuan tanpa panduan guru, mampu mencari dan menemukan pengetahuannya sendiri melalui aktifitas belajarnya dan mendorong siswa untuk berfikir tingkat tinggi. 


\section{SARAN}

Berdasarakan kesimpulan di atas maka penulis memberikan saran-saran sebagai berikut:

1. Pihak sekolah terus memberikan dukungan moril maupun materil terutama dalam hal peningkatan pemahaman guru terhadap konsep dan prinsip pembelajaran aktif dengan menugaskan guru untuk mengikuti pelatihan implementasi K-13, melakukan supervisi pembelajaran untuk memonitor pembelajaran secara keseluruhan agar pencapaian tujuan pembelajaran kompetensi sikap, pengetahuan dan keterampilan dapat tercapai.

2. Semua guru diharapkan untuk melek model dan strategi pembelajaran aktif dengan menumbuhkan keinginan untuk terus belajar dan menjadi guru pembelajar. Hal ini dibutuhkan untuk mencari bentuk inovasi pembelajaran yang lebih baik dari sekedar mempraktekakan model pembelajaran yang telah dipakai sebelumnya.

3. Sekolah terus membudayakan penerapan model-model pembelajaran dan memberi keleluasaan kepada guru dan siswa untuk melakukan inovasi pembelajaran.

4. Mendorong guru untuk melakukan penelitian kelas atau penelitian lainnya yang bertujuan untuk dapat menciptakan model pembelajaran aktif baru hasil penemuan guru karena menurut penulis model pembelajaran aktif itu sangat banyak dan terbuka bagi siapapun untuk menciptakan model baru yang lebih efektif dan berguna.

\section{DAFTAR PUSTAKA}

-----, 2016. Modul Pelatihan Guru Sasaran Kurikulum 2013. Jakarta. Dirjen PMPTK Kementrian dan Kebudayaan.

Abdul Aziz Wahab dan Sapriya, (2011). Teori dan Landasan Pendidikan Kewarganegaraan. Bandung. Alfabeta.

Abidin, Yunus. (2014). Desain Sistem Pembelajaran dalam Konteks Kurikulum 2013. Bandung. Refika Aditama

Agus, Salim. (2006). Teori dan Paradigma Penelitian Sosial. Yogyakarta: Tiara Wacana.

Al-Muchtar, Suwarma. (2015). Dasar penelitian Kualitatif. Bandung. Gelar Potensi Mandiri.

Arikunto, Suharsimi. (2006). Prosedur Penelitian Suatu Pendekatan Praktek, Cet. Ke 13, Jakarta. Rineka Cipta.

Arikunto, Suharsimi. (2010). Prosedur Penelitian Suatu Pendekatan Praktik. Yogyakarta: Rineka Cipta.

Asis Saefudin \& Ika Berdiati. (2015). Pembelajaran Efektif. PT. Remaja Rosda Karya. Bandung. 
Azwar, Saifudin. (2015). Sikap Manusia, Teori dan Pengukurannya. Yogyakarta. Pustaka Pelajar. Edisi kedua.

Badan Pengembangan Sumber Daya Manusia. (2013). Pedoman Penilaian Hasil Belajar. Jakarta: Kementerian Pendidikan dan Kebudayaan Republik Indonesia.

Bungin, H. M. Burhan, (2011). Penelitian Kualitatif, Jakarta. Prenada Media Group.

Creswell, John.W. (2015). Penelitian Kualitatif \& Desain Riset. Yogyakarta. Pustaka Pelajar.

Cucu Suhana. (2014). Konsep dan Strategi Pembelajaran. Edisi Revisi. Bandung. Refika Aditama.

Daniel J. Mueller. (1992). Mengukur Sikap Sosial Pegangan untuk Peneliti dan Praktisi. Jakarta: Bumi Aksara.

Hamzah B. Uno dan Satria Koni. (2012). Assessment Pembelajaran. Jakarta: Bumi Aksara.

Hamzah B. Uno, Haji. (2010). Model Pembelajaran. Jakarta. Sinar Grafika Offset.

Hisyam Zaini, dkk. (2008). Strategi Pembelajaran Aktif. Yogyakarta: Pustaka Insan Madani.

Idrus, Muhammad. (2009). Metode Penelitian Ilmu Sosial. Yogyakarta: Penerbit Erlangga,

Kasiram, H. Moh.. (2010), Metodologi Penelitian Kualitatif-Kuantitaif, Malang. UIN Maliki Press.

Kemendikbud. (2013). Peraturan Menteri Pendidikan dan Kebudayaan Nomor 66 Tahun 2013 tentang Standar Penilaian. Jakarta: Kemendikbud.

Machmudah dan Rosyidi, (2008). Active Learning dalam pembelajaran Bahasa Arab. Malang. UIN Malang Press.

Made Pidarta. (2000). Landasan Kependidikan. Jakarta: Rineka Cipta.

Mar'at, (1982). Sikap Manusia Perubahan serta Pengukuran. Jakarta. Ghalia Indonesia.

Margono S. Drs. (2007). Metologi Penelitian Pendidikan Komponen MKDK. PT. Rineka Cipta, Jakarta

Marno \& Idris. (2010). Strategi \& Model Pengajaran. Ar-Ruz Media Grup. Yohyakarta

Moleong, Lexy J., (2009). Metode Penelitian Kualitatif, Bandung. PT Remaja Rosdakarya.

Mulyasa, H.E. 2013. Pengembangan dan Implementasi Kurikulum 2013. Bandung. PT Remaja Rosda Karya.

Mulyasa, H.E. 2015. Guru dalam Implementasi Kurikulum 2013. Bandung. PT Remaja Rosda Karya. 
Mulyasana, Dedy. 2011. Pendidikan Bermutu dan Berdaya Saing. Bandung. PT Remaja Rosda Karya.

Nana Sudjana dan Ahmad Rivai, (2003). Teknlogi Pengajaran, Bandung: Sinar Baru Algensindo. cet. III.

Nasution. (2003). Metode Research: Penelitian Ilmiah. Jakarta: PT. Bumi Aksara

Nazir, Mohammad. 2005. Metode Penelitian. Bogor: Ghalia Indonesia.

Dominika-Niron, M. (2009). Pengembangan Silabus dan Rencana Pelaksanaan Pembelajaran dalam KTSP. Yogyakarta: Departemen Pendidikan Nasional UNY.

Putra, N. 2011. Penelitian Kualitatif: Proses dan Aplikasi. PT. Indeks - Jakarta.

Riduwan. 2004. Metode Riset. Jakarta: Rineka Cipta

Rusman, (2009). Manajemen Kurikulum. Jakarta. PT Raja Grafindo Persada

Rusman, (2014). Model-model Pembelajaran, Mengembangkan Profesionalis Guru. Jakarta. PT Raja Grafindo Persada.

Rusman, (2015). Pembelajaran Tematik Terpadu: Teori Praktik dan Penilaian. Jakarta. PT Raja Grafindo Persada.

Saifuddin Azwar. (2013). Sikap Manusia Teori dan Pengukurannya. Yogyakarta: Pustaka Pelajar.

Silberman, Melvin L. (2014). Active Learning. 101 Cara Belajar Siswa Aktif. Bandung. Nuansa Cendikia.

Soegeng Ysh., A.Y. 2012, Pengembangan Sistem Pembelajaran, Semarang, IKIP PGRI Semarang Press

Soetarno, R. 1989. Psikologi Sosial. Yogakarta: Kanisius

Stevenson, N. (2006). Young Person's Character Education Hand Book. Indianapolis: Jist Life.

Sugiyono. 2010. Metode Penelitian Kuantitatif Kualitatif dan R \& D. Bandung: Alfabeta

Sugiyono. 2012. Metode Penelitian Kuantitatif, Kualitatif, dan R\&D. Cetakan ke-17. Bandung: Alfabeta.

Sugiyono. 2013. Metode Penelitian Kuantitatif, Kualitatif, dan R\&D. Cetakan ke-19. Bandung: Alfabeta.

Sugiyono. 2016. Metode Penelitian Kuantitatif, Kualitatif, dan R\&D. Cetakan ke-24. Bandung: Alfabeta. 
Suyono, 2016. Belajar dan Pembelajaran. Bandung. PT Remaja Rosda karya

Warsono dan Hariyanto, 2013. Pembelajaran Aktif, Teori dan Asesmen. Bandung. PT Remaja Rosda Karya.

Winataputra dan Budimansyah, 2012. Pendidikan Kewarganegaraan dalam Presfektif Internasional. Bandung. Widya Aksara Press.

Winataputra, 2012. Pendidikan Kewarganegaraan dalam Presfektif Pendidikan untuk Mencerdaskan Kehidupan Bangsa. Bandung. Widya Aksara Press.

\section{Jurnal}

Edwards, Susan. (2015). Middle School Journal Department of Teacher Education at Georgia Regents University in Augusta, Georgia." Active learning in the middle grades" page 26. Retrieved from http://files.eric.ed.gov/fulltext/EJ1059827.pdf

Fadllan, Andi. (2010). "Strategi peningkatan keterampilan calon guru dalam menerapkan pembelajaran aktif melalui MEI (modelling, engaging, and integrating)". (Skripsi, IAIN Walisongo) dalam Jurnal Kreatif. IAIN Walisongo. Diunduh://journal.walisongo.ac.id/index.php/Nadwa/article/download/519/468

Fu'at, Fauzi. (2015). Pendidikan Spiritual dalam Mengembangkan Karakter Prespektif Imam Al-Gazali. (Skripsi, IAIN Sunan Kalijaga). Diunduh darihttp://digilib.uinsuka.ac.id/16267/1/BAB\%20I\%2C\%20V\%2C\%20DAFTAR\%20P USTAKA.pdf

Panjaitan, MD. (2012). Bab II Landasan Teori A. Sikap 1. Definisi sikap Mekanisme. (Skripsi Universitas Sumatra Utara, 2012). Diunduh dari http://repository.usu.ac.id/bitstream/123456789/19289/4/Chapter\%20II.pdf

Mufatihah, M. (2014). Bab II Landasan Teori A. Deskripsi Teori 1. Sikap Spiritual. (Skripsi IAIN Walisongo, 2014). Diunduh dari http://eprints.walisongo.ac.id/3709/3/093111073_bab2.pdf

Nurhayati, E, (2008). Pengaruh Penggunaan Metode Belajar Aktif Tipe Team quiz Terhadap Minat Belajar Dan Hasil Belajar Kuntansi Siswa Kelas X Ak Smk Negeri 3 Jepara Tahun 2006/2007. (Skripsi Universitas Negeri Semarang, 2008) diunduhrepository.uksw.edu/bitstream/123456789/../T1_292008151_Daftar\%20Pustak a.pdf

Prince, M. (2004). Does Active Learning Work? A Review of the Research. Journal of Engineering Education Department of Chemical Engineering Bucknell University, 3, 223-221.

http://www4.ncsu.edu/unity/lockers/users/f/felder/public/Papers/Prince_AL.pdf

Khithok Ahmad Purwanto (2009). Penerapan Model Pembelajaran Aktif, Kreatif, Efektif Dan Menyenangkan (Pakem) Pada Mata Pelajaran Pkn (Suatu Studi Di Mts Negeri I Malang) diunduh dari http://jurnalonline.um.ac.id/data/artikel/artikel60F5672FD91605E8C0EC357BDE33368C.pdf. 
Ramli Abdullah, (2012). Pembelajaran Berbasis Pemanfaatan Sumber Belajar diunduh dari http://jurnal.ar raniry.ac.id/index.php/didaktika/article/viewFile/449/360

Jumaidi Nur, (2015). Pengaruh Sarana Belajar Terhadap Minat Belajar Siswa Kelas Viii Smp Negeri 4 Tenggarong. Yang diunduh dari: ejurnal.unikarta.ac.id/index.php/cemerlang/article/download/46/33

Bekti Wulandari, (2013). Pengaruh Problem-Based Learning Terhadap Hasil Belajar Ditinjau Dari Motivasi Belajar Plc Di SMK. Diunduh dari: http://staff.uny.ac.id/sites/default/files/penelitian/Herman\%20Dwi\%20Surjono,\%20Drs. \%20M.Sc.,\%20MT.,\%20Ph.D./jurnal\%20vokasi\%20juni\%202013.pdf

Yulinda Siregar, (2015). Kompetensi Guru Dalam Bidang Strategi Perencanaan Dan Pembelajaran Matematika. Yang diunduh dari jurnal: http://journal.lppmunindra.ac.id/index.php/Formatif/article/viewFile/114/111

\section{Peraturan Perundangan}

Undang-Undang Nomor 20 Tahun 2003 tentang Sistem Pendidikan Nasional.

Peraturan Menteri Pendidikan dan Kebudayaan No. 59, Tahun 2014 tentang Kurikulum 2013 Sekolah Menengah Atas/Madrasah Aliyah.

Peraturan Menteri Pendidikan dan Kebudayaan No. 103, Tahun 2014 tentang Pembelajaran Pada Pendidikan Dasar dan Pendidikan Menengah.

Peraturan Menteri Pendidikan dan Kebudayaan No. 20, Tahun 2016 tentang Standar Kompetensi Lulusan Pendidikan Dasar dan Menengah.

Peraturan Menteri Pendidikan dan Kebudayaan No. 21, Tahun 2016 Standar Isi Pendidikan Dasar dan Menengah

\section{Sumber online dan bentuk lain}

https://gurupembelajar.id/. Diakses pada tanggal 08 September 2016 pukul 09.12 WIB.

https://www.kaganonline.com/download/BKCL-toc.pdf. Diakses pada tanggal 09 September 2016 pukul 11.05 WIB.

Muhammad, Alfian. (2013, April 10) Teori Sikap. Diposting pada http://hanajadeh.blogspot.co.id/2013/04/teori-sikap.html

Fitriannisa, (2015, November 5) halaman artikel pendidikan. Diposting pada. /https://fitriannisa259.wordpress.com/artikel-pendidikan/artikel-sikap-sosial/ 